\title{
Thiohalobacter thiocyanaticus gen. nov., sp. nov., a moderately halophilic, sulfur-oxidizing gammaproteobacterium from hypersaline lakes, that utilizes thiocyanate
}

\author{
Correspondence \\ Dimitry Yu. Sorokin \\ soroc@inmi.host.ru or \\ d.y.sorokin@tudelft.nl
}

\author{
Dimitry Yu. Sorokin, ${ }^{1,2}$ Olga L. Kovaleva, ${ }^{3}$ Tatjana P. Tourova ${ }^{1}$ \\ and Gerard Muyzer ${ }^{2}$ \\ ${ }^{1}$ Winogradsky Institute of Microbiology, Russian Academy of Sciences, Prospect 60-let Octyabrya \\ 7/2, 117811 Moscow, Russia \\ ${ }^{2}$ Department of Biotechnology, Delft University of Technology, Julianalaan 67, 2628 BC Delft, The \\ Netherlands \\ ${ }^{3}$ Department of Microbiology, Faculty of Biology, Moscow State University, Moscow, Russia
}

\begin{abstract}
A moderately halophilic, obligately chemolithoautotrophic, sulfur-oxidizing bacterium, designated strain $\mathrm{HRh} 1^{\top}$, was obtained from mixed sediment samples from hypersaline chloride-sulfate lakes in the Kulunda Steppe, in south-western Siberia (Russia), using aerobic enrichment culture at $1 \mathrm{M}$ $\mathrm{NaCl}$ with thiocyanate as substrate. Cells of the isolate were short, non-motile rods with a Gramnegative type of cell wall. The bacterium was an obligate aerobe capable of chemolithoautotrophic growth with thiocyanate and thiosulfate. With thiosulfate, it grew at $\mathrm{NaCl}$ concentrations of $0.2-$ 3.0 M (optimum 0.5 M) and at pH 6.3-8.0 (optimum pH 7.3-7.5). During growth on thiocyanate, cyanate was identified as an intermediate. The dominant cellular fatty acids were $\mathrm{C}_{16: 0}$ and $\mathrm{C}_{18: 1} \omega 7$. Phylogenetic analysis based on 16S rRNA gene sequencing placed the isolate in the class Gammaproteobacteria as an independent lineage, with an unclassified marine sulfuroxidizing bacterium as the closest culturable relative ( $93 \%$ sequence similarity). A single $c b b L$ gene (coding for the key enzyme of the Calvin-Benson cycle of autotrophic $\mathrm{CO}_{2}$ assimilation) with relatively low similarity to any homologous genes found in chemolithoautotrophs was detected in strain $\mathrm{HRh} 1^{\top}$. On the basis of our phenotypic and phylogenetic analysis, the halophilic isolate is proposed to represent a new genus and novel species, Thiohalobacter thiocyanaticus gen. nov., sp. nov. The type strain of Thiohalobacter thiocyanaticus is $\mathrm{HRh} 1^{\top}$ (=DSM $21152^{\top}$ $=$ UNIQEM U $249^{\top}$ ).
\end{abstract}


To date, microbial thiocyanate utilization at extremely high salt concentrations and neutral $\mathrm{pH}$ has not been reported. Our recent survey of hypersaline habitats with neutral $\mathrm{pH}$ revealed an unexpectedly rich diversity of culturable $\mathrm{SOB}$ represented by six different phylogenetic lineages of moderate and extremely halophilic SOB within the Gammaproteobacteria (Sorokin et al., 2006; Sorokin, 2008). One of the moderately halophilic groups among them, represented by the novel genus and species Thiohalophilus thiocyanatoxidans, is capable of growth with thiocyanate, both aerobically and anaerobically with nitrite (at concentrations below $2 \mathrm{mM}$ ) at $1-4 \mathrm{M} \mathrm{NaCl}$ (Sorokin et al., 2007a). It formed COS as an intermediate during thiocyanate degradation and the enzyme responsible for the reaction was identified as thiocyanate hydrolase (Bezsudnova et al., 2007). Aerobic enrichments from hypersaline lakes with thiocyanate as substrate were only positive at salt concentrations of $2 \mathrm{M}$ and lower. One such enrichment from a mixture of lake sediments resulted in the isolation of strain $\mathrm{HRh}^{\mathrm{T}}$, a thiocyanate-utilizing, moderately halophilic SOB which is characterized in this paper.

Surface sediments from several hypersaline chloride-sulfate lakes in the Kulunda Steppe (south-west Siberia, Altai, Russia) were used for the enrichment of halophilic SOB with total salt concentration of the brines from 20 to $38 \%$ $(\mathrm{w} / \mathrm{v})$ and $\mathrm{pH}$ 7.5-8.5.

The mineral base medium used for enrichment and growth experiments contained $1-4 \mathrm{M} \mathrm{NaCl}$ and $10 \mathrm{mM} \mathrm{K}_{2} \mathrm{HPO}_{4}$. The $\mathrm{pH}$ was adjusted to 7.5 with $10 \% \mathrm{KH}_{2} \mathrm{PO}_{4}$. After sterilization, the medium was supplemented with $2 \mathrm{mM}$ $\mathrm{MgCl}_{2} \cdot 6 \mathrm{H}_{2} \mathrm{O}$ and $1 \mathrm{ml}$ trace metal solution $\mathrm{I}^{-1}$ (Pfennig \& Lippert, 1966). Potassium thiocyanate $(5 \mathrm{mM})$ or sodium thiosulfate $(20 \mathrm{mM})$ were used as electron donors from filter-sterilized $1 \mathrm{M}$ solutions. In the case of thiosulfate, the medium was also supplemented with $4 \mathrm{mM} \mathrm{NH}_{4} \mathrm{Cl}$. Filtersterilized $\mathrm{NaHCO}_{3}(1 \mathrm{M}, \mathrm{pH}$ 8.0) was added as a carbon source and a buffer at a final concentration of $10-40 \mathrm{mM}$. Routine aerobic incubation was performed in closed bottles with the liquid/gas ratio of 10:90 with shaking at 100 r.p.m. and at $30{ }^{\circ} \mathrm{C}$ for 5-20 days, depending on the substrate and salt concentration. Growth under denitrifying conditions was studied as described previously (Sorokin et al., 2007a). Growth was monitored by following the optical density at $590 \mathrm{~nm}$, substrate consumption and products formation. A pure culture was obtained from well-separated sulfur-containing colonies formed on solid medium with thiocyanate at $1 \mathrm{M} \mathrm{NaCl}$ after plating serially diluted enrichment culture stabilized by several 1:100 transfers. Culture purity was checked by microscopy, sequencing and by the absence of growth on rich organic medium in which thiocyanate was replaced by yeast extract.

Sulfur (thiocyanate, thiosulfate, tetrathionate and sulfate) and nitrogen (cyanate, $\mathrm{NH}_{3}$ ) compounds were analysed as described previously (Sorokin et al., 2001, 2007a). Cell protein was measured by using the Lowry method (Lowry et al., 1951) after removal of interfering sulfur compounds: soluble sulfur compounds were removed by washing (thiosulfate, tetrathionate) and insoluble sulfur was extracted from the cell pellet by overnight incubation with acetone. Phase-contrast photomicrographs were obtained using microscope model Zeiss Axioplan Imaging 2. For electron microscopy, the cells were fixed in glutaraldehyde (final concentration $3 \%, \mathrm{v} / \mathrm{v}$ ) in $0.5 \mathrm{M} \mathrm{NaCl}$ and, after removal of the fixative, were stained with $2 \%(\mathrm{w} / \mathrm{v})$ uranyl acetate. Other analyses (such as respiration tests and activity measurements) were performed as described previously (Sorokin et al., 2007a).

Aerobic enrichments with thiocyanate as electron donor at 1-4 $\mathrm{M} \mathrm{NaCl}$ gave positive results only at $\mathrm{NaCl}$ concentrations of $1-2 \mathrm{M}$. The cultures consumed $10 \mathrm{mM}$ thiocyanate within a month with sulfate as the final product. Plating of the $1 \mathrm{M} \mathrm{NaCl}$ culture as the most active one after several repetitive transfers resulted in the formation of tiny sulfur-containing colonies with an identical cell morphology after 3 weeks of incubation. One such colony resulted in a positive liquid culture that grew with thiocyanate at $1 \mathrm{M} \mathrm{NaCl}$, which was designated strain $\mathrm{HRh} 1^{\mathrm{T}}$. The culture was represented by short, non-motile rods, often in chains and clusters (Fig. 1).

The novel bacterium was an obligately chemolithoautotrophic SOB, growing with either thiocyanate or thiosulfate as electron donor under strictly aerobic conditions. Growth with thiocyanate was very slow and, in many cases, the culture consumed only 5-10 mM substrate and then failed to grow any more on further additions. The final products of thiocyanate metabolism were sulfate and ammonia, and cyanate (but not COS) was identified as an intermediate (Fig. 2a). Growth with thiosulfate was much faster and resulted in much higher biomass. The final product was sulfate (Fig. 2b), with occasional intermediate formation of elemental sulfur because of oxygen limitation. The latter was utilized when the culture was supplied with extra air through an inserted air filter. Tetrathionate was formed from thiosulfate in minor amounts only at a highest salt concentration $(3 \mathrm{M})$. The maximal experimentally measured growth yield and specific growth rate for strain $\mathrm{HRh} 1^{\mathrm{T}}$ during cultivation at $1 \mathrm{M} \mathrm{NaCl}$ on thiocyanate/ thiosulfate were $4.0 / 4.4 \mathrm{mg}$ protein $\mathrm{mmol}^{-1}$ and $0.015 /$ $0.045 \mathrm{~h}^{-1}$, respectively.

Apart from thiocyanate and thiosulfate, sulfide, tetrathionate and elemental sulfur could also be oxidized by washed cells of $\mathrm{HRh}^{\mathrm{T}}$ obtained from late-exponential-growth phase cultures pregrown either with thiocyanate or thiosulfate. However, attempts to grow the culture with these compounds failed. The rates of oxygen consumption $\left[\mathrm{nmol} \mathrm{O}{ }_{2} \text { (mg protein }\right)^{-1} \mathrm{~min}^{-1}$; means of two independent experiments] at $1 \mathrm{M} \mathrm{NaCl}$ measured in two samples with cells grown with either thiocyanate or thiosulfate were 75 and 0 with thiocyanate, 65 and 350 with thiosulfate, 130 and 480 with sulfide, 20 and 200 with tetrathionate and 60 

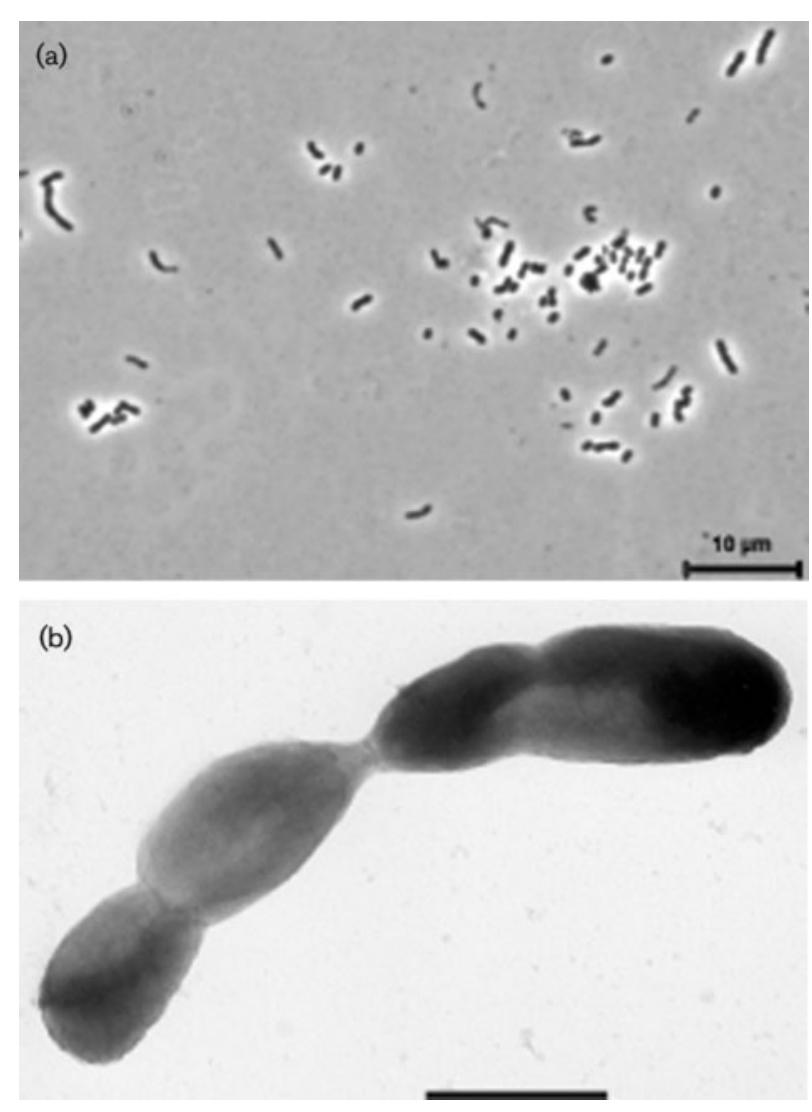

Fig. 1. Cell morphology of strain $\mathrm{HRh}^{\top}{ }^{\top}$ grown at $1 \mathrm{M} \mathrm{NaCl}$ with thiocyanate. (a) Phase-contrast microphotograph; (b) electron photomicrograph of fixed, intact cells. Bars, $10 \mu \mathrm{m}$ (a) and $1 \mu \mathrm{m}$ (b).

and 240 with sulfur (solution in acetone), respectively. Thiocyanate-degrading activity was therefore only manifested in cells grown with thiocyanate, while, with the other inorganic sulfur compounds, the activity was present in both preparations but was much higher in the thiosulfategrown cells.

Strain $\mathrm{HRh} 1^{\mathrm{T}}$ was able to grow with thiosulfate at a $\mathrm{NaCl}$ concentration $0.2-3.0 \mathrm{M}$, with optimum growth at $0.5 \mathrm{M}$ (Fig. 3a), meaning it is classified as a moderate halophile. Washed cells were active at up to $4 \mathrm{M} \mathrm{NaCl}$, with an optimum at $1-1.5 \mathrm{M}$. Cells grown in $1 \mathrm{M} \mathrm{NaCl}$ were obviously less active at high salt than cells pregrown at a maximum salinity of $3 \mathrm{M}$ (Fig. $3 \mathrm{~b}$ ). There was also a dramatic difference in product formation from thiosulfate oxidized by the washed cells: cells grown at $3 \mathrm{M} \mathrm{NaCl}$ performed complete oxidation of thiosulfate to sulfate over the entire salinity range, while cells grown at $1 \mathrm{M} \mathrm{NaCl}$ oxidized thiosulfate incompletely to tetrathionate at high salt (Fig. 3b). The latter fact pointed to a blockade of tetrathionate oxidation at high salt in cells grown at low salinity.

Washed cells obtained from thiocyanate-grown cultures were able to degrade thiocyanate only under aerobic
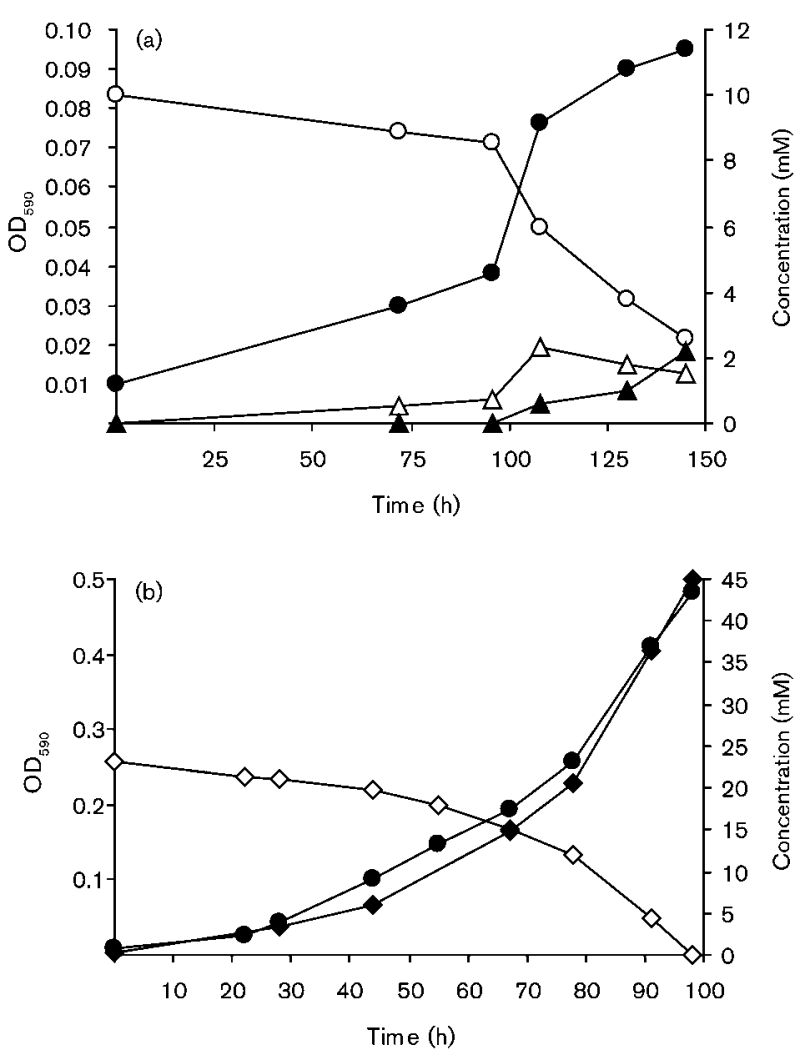

Fig. 2. Growth and product formation in autotrophic cultures of strain $\mathrm{HRh} 1^{\top}$ with thiocyanate at $1 \mathrm{M} \mathrm{NaCl}$ (a) and with thiosulfate at $2 \mathrm{M} \mathrm{NaCl}$ (b). $\bullet$, Biomass (as $\mathrm{OD}_{590}$ ); $\bigcirc$, thiocyanate; $\diamond$, thiosulfate; $\triangle$, ammonia; $\boldsymbol{\Delta}$, cyanate; $\boldsymbol{\nabla}$, sulfate.

conditions. Ultrasonic cell disruption completely abolished the thiocyanate-degrading activity. Under aerobic conditions, washed cells oxidized thiocyanate to sulfate and ammonium at a maximum specific rate of $15 \mathrm{nmol}(\mathrm{mg}$ protein $)^{-1} \min ^{-1}$. Cyanate was produced as a nitrogen intermediate at a maximum yield of $40 \%$ from the metabolized thiocyanate nitrogen. However, cyanase activity was not detectable either in whole cells or in cell-free extracts. These data confirmed that $\mathrm{HRh}^{\mathrm{T}}$ uses the cyanate pathway for thiocyanate degradation and also show that the presence of cyanase activity cannot be taken as an indicator of the operation of this pathway, as was found previously for Thioalkalivibrio strains (Sorokin et al., 2001).

Cellular fatty acids were extracted from freeze-dried biomass of strain $\mathrm{HRh} 1{ }^{\mathrm{T}}$ grown at $2 \mathrm{M} \mathrm{NaCl}$ and $30{ }^{\circ} \mathrm{C}$ with thiosulfate by acidic methanol extraction and analysed by GC-MS according to Zhilina et al. (1997). The analysis demonstrated that two unsaturated species $\left(\mathrm{C}_{16: 1} \omega 07\right.$ and $\left.\mathrm{C}_{18: 1} \omega 7\right)$ and saturated $\mathrm{C}_{16: 0}$ made up more than $80 \%$ of the total. In this, it resembled the fatty acid composition of the moderately halophilic Thiohalomonas denitrificans (Sorokin et al., 2007b). On the other hand, the presence of the 10-methyl $\mathrm{C}_{16: 0}$ species at a relatively high 

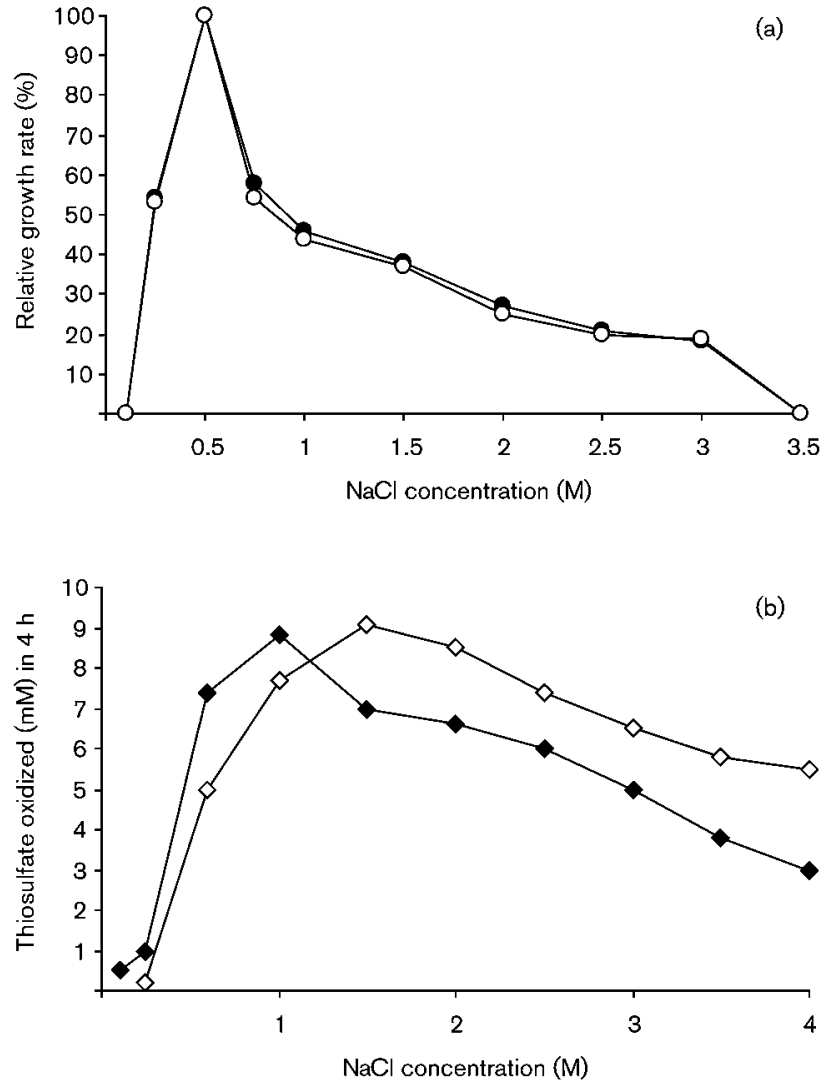

Fig. 3. Influence of $\mathrm{NaCl}$ on growth of strain $\mathrm{HRh}^{\top}{ }^{\top}$ with thiosulfate at $\mathrm{pH} 7.5$ (a) and on activity of thiosulfate oxidation by washed cells (b). $\bigcirc$, Biomass; $\bullet$, rate of thiosulfate consumption during growth; $\boldsymbol{\nabla}$, activity of thiosulfate oxidation by cells grown at $1 \mathrm{M} \mathrm{NaCl} ; \diamond$, activity of thiosulfate oxidation by cells grown at $3 \mathrm{M} \mathrm{NaCl}$.

concentration was more characteristic of extremely halophilic SOB of the genera Thiohalospira and Thiohalorhabdus isolated from the same habitats (Sorokin, 2008) (see Supplementary Table S1, available in IJSEM Online).

Spectroscopic analysis of cell membranes of strain HRh1 ${ }^{\mathrm{T}}$ showed a higher concentration of the $b$-type cytochromes in the cells grown with thiocyanate than those grown with thiosulfate. The CO-spectra indicated the presence of $c b$ type cytochrome oxidase in both preparations (most

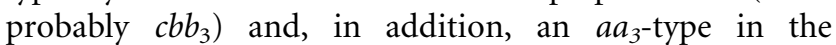
thiocyanate-growing cells (data not shown).

Genomic DNA was extracted by using the phenol/ chloroform method (Marmur, 1961) and the G+C content was analysed by using the thermal denaturation/ reassociation technique (Marmur \& Doty, 1962) with DNA from Escherichia coli $\mathrm{K}-12$ as a standard. The DNA G + C content was $63.5 \mathrm{~mol} \%$. A nearly complete $16 \mathrm{~S}$ rRNA gene (1455 bp) was amplified using the general bacterial primers GM3F and GM4R (Schäfer \& Muyzer, 2001). To amplify a $c b b L$ gene fragment (800 bp), coding for the ribulose bisphosphate carboxylase/oxygenase (RuBisCO) large subunit form I, a specially designed primer pair and protocol were used (Spiridonova et al., 2004). The PCR products were purified from low-melting-point agarose using the Wizard PCR-Prep kit (Promega) according to the manufacturer's instructions. Phylogenetic trees were reconstructed using the TREECON w package (Van de Peer \& De Wachter, 1994).

16S rRNA gene sequence analysis demonstrated that strain $\mathrm{HRh}^{\mathrm{T}}$ formed an independent lineage within the Gammaproteobacteria with an unidentified marine denitrifying SOB isolate as the closest cultured relative (93\% sequence similarity) (Fig. 4a). A search of the RDP database indicated a $100 \%$ match to the Gammaproteobacteria and $85 \%$ probability of affiliation with the Chromatiales. Among uncultured clones, a BLAST search using the sequence identified a group of unclassified marine gammaproteobacteria as the closest relatives, with $95 \%$ sequence similarity (Hunter et al., 2006).

A single $c b b L$ gene of the 'green-like' form I RuBisCO was detected in strain $H R h 1^{\mathrm{T}}$. Phylogenetic analysis placed the sequence within a cluster of lithoautotrophic bacteria from the Gammaproteobacteria and Betaproteobacteria as an independent lineage (Fig. 4b).

The presented data demonstrate that the novel thiocyanate-utilizing halophilic SOB isolate $\mathrm{HRh} 1^{\mathrm{T}}$ differs in many respects from its counterparts from the same habitats (Thiohalophilus species), in both the mechanism of thiocyanate degradation and other essential phenotypic and phylogenetic properties (Table 1). On the basis of these unique features, a new genus and species Thiohalobacter thiocyanaticus gen. nov., sp. nov. are proposed here to accommodate strain $\mathrm{HRh}^{\mathrm{T}}$.

\section{Description of Thiohalobacter gen. nov.}

Thiohalobacter (Thi'o.ha.lo.bac'ter. Gr. n. thion sulfur; Gr. n. hals, halos salt; N.L. masc. n. bacter a rod; N.L. masc. n. Thiohalobacter halophilic sulfur rod).

Gram-negative, aerobic, obligately chemolithoautotrophic sulfur-oxidizing bacteria. $\mathrm{CO}_{2}$ is assimilated through the Calvin-Benson cycle. Oxidize inorganic sulfur compounds to sulfate. Moderately halophilic and neutrophilic. Major cellular fatty acids are $\mathrm{C}_{16}$ and $\mathrm{C}_{18}$ species. The known strain was isolated from a hypersaline habitat. The genus is a member of the Gammaproteobacteria. The type species is Thiohalobacter thiocyanaticus.

\section{Description of Thiohalobacter thiocyanaticus sp. nov.}

Thiohalobacter thiocyanaticus (thi'o.cy.a.na'ti.cus. N.L. n. thiocyanas -atis thiocyanate; L. masc. suff. -icus suffix used in adjectives with the sense of belonging to; N.L. masc. adj. thiocyanaticus related to thiocyanate, utilizing thiocyanate). 
(a)

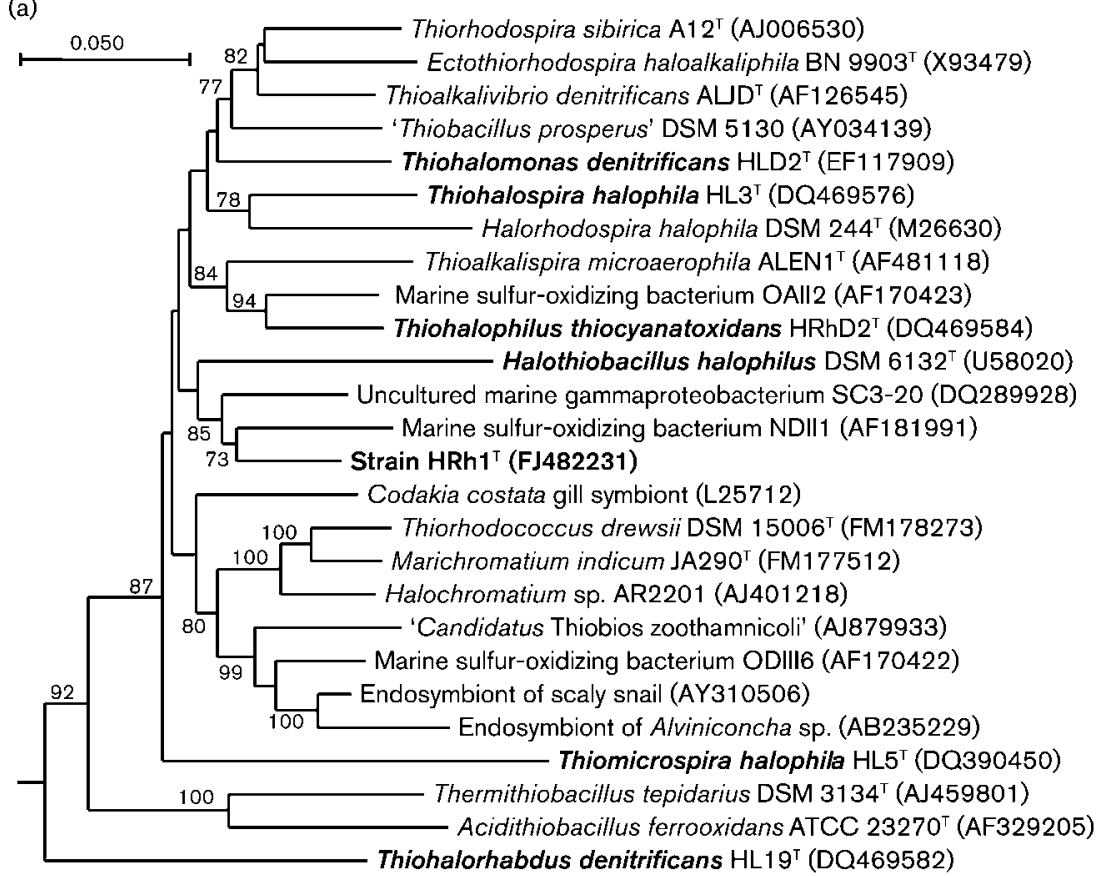

(b) $\quad$ Acidithiobacillus ferrooxidans ATCC 23270 (AF307091) (cbbL-1) Nitrosomonas europaea ATCC 19718 (NC_004757)

95 Strain HRh1T (FJ716702)

Thiobacillus thioparus DSM $505^{\top}$ (DO390449)

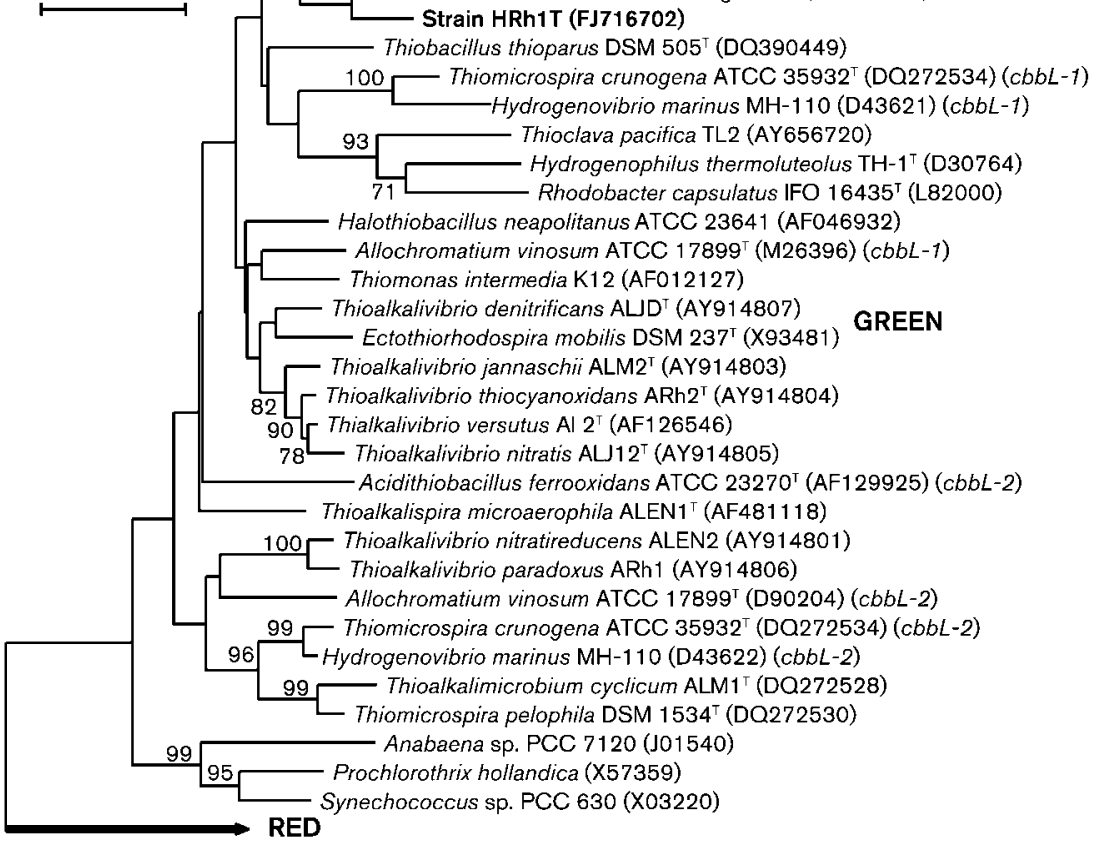

Fig. 4. Phylogenetic position of strain $H R h 1^{\top}$ within the Gammaproteobacteria based on $16 \mathrm{~S}$ rRNA gene sequence analysis (a) and based on inferred amino acid sequence of the $c b b L$ gene (b). The trees were reconstructed from evolutionary distances by using the neighbour-joining method. In (a) the outgroup (Desulfurivibrio alkaliphilus AHT $2^{\top}$; GenBank accession no. EF422413) was pruned from the tree. In (a), halophilic SOB isolated from the same habitat as strain $\mathrm{HRh} 1^{\top}$ are highlighted. Bootstrap percentages was derived from 1000 resamplings; values greater than $70 \%$ were considered as significant. Bars, 0.05 (a) and 0.1 (b) substitutions per nucleotide position. 
Table 1. Comparison of properties of strain $\mathrm{HRh} 1^{\top}$ with other moderately halophilic SOB from the Gammaproteobacteria

Strains/species: 1, HRh1 ${ }^{\mathrm{T}}$; 2, Thiohalophilus thiocyanatoxidans (data from Sorokin et al., 2007a); 3, Thiohalomonas denitrificans (Sorokin et al., 2007b); 4, Halothiobacillus halophilus (Wood \& Kelly, 1991; Kelly et al., 1998). ND, No data available. All taxa oxidize thiosulfate, sulfide and inorganic sulfur.

\begin{tabular}{|c|c|c|c|c|}
\hline Property & 1 & 2 & 3 & 4 \\
\hline Motility & - & - & - & + \\
\hline Thiocyanate utilization & + (via cyanate) & $+($ via COS $)$ & - & - \\
\hline Denitrification & - & + (nitrite) & + (nitrate) & - \\
\hline Tetrathionate & + & + & - & + \\
\hline Trithionate, hexathionate & - & - & - & + \\
\hline Tetrathionate formation from thiosulfate & + & - & - & + \\
\hline Salt tolerance $(\mathrm{M} \mathrm{NaCl})$ & 3.0 & 4.0 & 3.0 & 4.0 \\
\hline RuBisCO form & I & $I^{*}$ & $\mathrm{II}^{*}$ & $I^{*}$ \\
\hline DNA G $+C$ content $(\mathrm{mol} \%)$ & 63.5 & 58.2 & $58-60$ & 64.2 \\
\hline
\end{tabular}

*Our unpublished data.

Shows the following properties in addition to those described for the genus. Cells are short non-motile rods, often in chains, $0.4 \times 1-2 \mu \mathrm{m}$. Colonies are up to $2 \mathrm{~mm}$ in diameter, silverwhite from extracellular sulfur accumulation. The dominant cellular fatty acids include $\mathrm{C}_{16: 1} \omega 7, \mathrm{C}_{18: 1} \omega 7$ and $\mathrm{C}_{16: 0}$. Oxidase- and catalase-positive. Utilizes thiocyanate and thiosulfate as electron donors. Oxidizes sulfide, elemental sulfur and tetrathionate but not $\mathrm{H}_{2}$. Thiocyanate is degraded under strictly aerobic conditions via cyanate. Grows at $0.2-$ 3.0 M NaCl (optimum 0.5 M), pH 6.3-8.0 (optimum $\mathrm{pH} 7.3-7.5$ ) and $20-40{ }^{\circ} \mathrm{C}$ (optimum $32{ }^{\circ} \mathrm{C}$ ). The $\mathrm{G}+\mathrm{C}$ content of the DNA of the type strain is $63.5 \mathrm{~mol} \%\left(T_{\mathrm{m}}\right)$.

The type strain, HRh $1^{\mathrm{T}}$ (=DSM $21152^{\mathrm{T}}=\mathrm{UNIQEM}$ $\left.\mathrm{U} 249^{\mathrm{T}}\right)$, was isolated from sediments of hypersaline lakes in south-western Siberia.

\section{Acknowledgements}

This work was supported by the RFBR (grant 010-04-00152) and FEMS (to O.L.K.). We thank G. Osipov for the analysis of cellular fatty acids and A. Lysenko for the total DNA analysis.

\section{References}

Bezsudnova, E. Yu., Sorokin, D. Yu., Tichonova, T. V. \& Popov, V. O. (2007). Thiocyanate hydrolase, the primary enzyme initiating thiocyanate degradation in the novel obligately chemolithoautotrophic halophilic sulfur-oxidizing bacterium Thiohalophilus thiocyanoxidans. Biochim Biophys Acta 1774, 1563-1570.

Hunter, E. M., Mills, H. J. \& Kostka, J. E. (2006). Microbial community diversity associated with carbon and nitrogen cycling in permeable shelf sediments. Appl Environ Microbiol 72, 5689-5701.
Katayama, Y., Matsushita, Y., Kaneko, M., Kondo, M., Mizuno, T. \& Nyunoya, H. (1998). Cloning of genes coding for the subunits of thiocyanate hydrolases of Thiobacillus thioparus THI 115 and their evolutionary relationships to nitrile hydratase. J Bacteriol 180, 25832589.

Kelly, D. P. \& Baker, S. C. (1990). The organosulfur cycle: aerobic and anaerobic processes leading to turnover of $\mathrm{C}_{1}$-sulfur compounds. FEMS Microbiol Rev 87, 241-246.

Kelly, D. P., Stackebrandt, E., Burghardt, J. \& Wood, A. P. (1998). Confirmation that Thiobacillus halophilus and Thiobacillus hydrothermalis are distinct species within the $\gamma$-subclass of the Proteobacteria. Arch Microbiol 170, 138-140.

Lowry, O. H., Rosebrough, N. J., Farr, A. L. \& Randall, R. J. (1951). Protein measurement with Folin phenol reagent. J Biol Chem 193, 265-275.

Marmur, J. (1961). A procedure for the isolation of deoxyribonucleic acid from microorganisms. J Mol Biol 3, 208-218.

Marmur, J. \& Doty, P. (1962). Determination of the base composition of deoxyribonucleic acid from microorganisms. J Mol Biol 5, 109-118.

Pfennig, N. \& Lippert, K. D. (1966). Über das Vitamin $B_{12}$-Bedürfnis phototropher Schwefelbacterien. Arch Mikrobiol 55, 245-256 (in German).

Schäfer, H. \& Muyzer, G. (2001). Denaturing gradient gel electrophoresis in marine microbial ecology. Methods Microbiol 30, 425-468.

Sorokin, D. Yu. (2008). Diversity of halophilic sulfur-oxidizing bacteria in hypersaline habitats. In Microbial Sulfur Metabolism, pp. 225-237. Proceedings of the International Symposium on Microbial Sulfur Metabolism, 29 June-2 July 2006. Edited by C. Dahl \& C. G. Friedrich. Münster: Springer.

Sorokin, D. Yu., Tourova, T. P., Lysenko, A. M. \& Kuenen, J. G. (2001). Microbial thiocyanate utilization under highly alkaline conditions. Appl Environ Microbiol 67, 528-538.

Sorokin, D. Yu., Tourova, T. P., Lysenko, A. M. \& Muyzer, G. (2006). Culturable diversity of halophilic sulfur-oxidizing bacteria in hypersaline habitats. Microbiology 152, 3013-3023. 
Sorokin, D. Yu., Tourova, T. P., Bezsoudnova, E. Yu., Pol, A. \& Muyzer, G. (2007a). Denitrification in a binary culture and thiocyanate metabolism in Thiohalophilus thiocyanatoxidans gen. nov. sp. nov. - a moderately halophilic chemolithoautotrophic sulfur-oxidizing gammaproteobacterium from hypersaline lakes. Arch Microbiol 187, 441-450.

Sorokin, D. Yu., Tourova, T. P., Bracker, G. \& Muyzer, G. (2007b). Thiohalomonas denitrificans gen. nov. sp. nov. and Thiohalomonas nitratireducens sp. nov., novel obligately chemolithoautotrophic, moderately halophilic, thiodenitrifying gammaproteobacteria from hypersaline habitats. Int J Syst Evol Microbiol 57, 1582-1589.

Spiridonova, E. M., Berg, I. A., Kolganova, T. V., Ivanovskii, R. N., Kuznetsov, B. B. \& Turova, T. P. (2004). An oligonucleotide primer system for amplification of the ribulose-1,5-bisphosphate carboxy- lase/oxygenase genes of bacteria of various taxonomic groups. Microbiology (English translation of Mikrobiologiia) 73, 377-387.

Van de Peer, Y. \& De Wachter, R. (1994). TREECON for Windows: a software package for the construction and drawing of evolutionary trees for the Microsoft Windows environment. Comput Appl Biosci 10, 569-570.

Wood, A. P. \& Kelly, D. P. (1991). Isolation and characterisation of Thiobacillus halophilus sp. nov., a sulphur-oxidizing autotrophic eubacterium from a Western Australian hypersaline lake. Arch Microbiol 156, 277-280.

Zhilina, T. N., Zavarzin, G. A., Rainey, F. A., Pikuta, E. N., Osipov, G. A. \& Kostrikina, N. A. (1997). Desulfonatronovibrio hydrogenovorans gen. nov., sp. nov., an alkaliphilic, sulfate-reducing bacterium. Int J Syst Bacteriol 47, 144-149. 